\title{
HUMAN MOVEMENT DETECTION DENGAN ACCUMULATIVE DIFFERENCES IMAGE
}

\author{
Mohamad Faisal Kholid'), Jian Budiarto ${ }^{2}$, Ahmad Ashril Rizal ${ }^{3)}$, Gibran Satya Nugraha ${ }^{4}$ \\ ${ }^{1,2,3,4)}$ Jurusan Ilmu Komputer Universitas Bumigora \\ e-mail: faisal.kholid62@ gmail.com ${ }^{1)}$, jian.budiarto@ gmail.com ${ }^{2}$, ashril.rizal@ gmail.com $^{3)}$, gibransn@un-

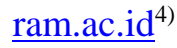

\begin{abstract}
ABSTRAK
Berdasarkan data kepolisian yang dikutip dari salah satu laman portal berita online terdapat 43.842 ribu aksi kejahatan yang ada di Ibu Kota Jakarta. Dari semua kasus kejahatan tersebut pembobolan rumah kosong termasuk dalam tiga besar aksi kriminalitas. Rumah yang ditinggal oleh pemiliknya seringkali dijadikan target operasi kejahatan dikarenakan pengawasan yang kurang ketat dan teknologi penunjang keamanan.

Tujuan dari penelitian ini adalah untuk mendeteksi gerak manusia yang nantinya bisa digunakan untuk mencegah terjadinya kejahatan berupa pencurian. Tujuan lain dari penelitian ini adalah untuk mengetahui bagaimana metode yang digunakan bekerja dalam mengidentifikasi perubahan citra dari beberapa frame yang berurutan. Penelitian ini mengembangkan sebuah sistem deteksi gerak pada manusia pada video menggunakan kamera Closed Circuit Television (CCTV) dimana dilakukan simulasi menggunakan video sampel.

Proses pendeteksian gerak menggunakan metode Accumulative Differences Image (ADI) dan proses deteksi manusia mengguakan klasifikasi dari Opencv yaitu Haar Casscade Clasification. Yang dimana dengan metode tersebut membandingkan lebih dari dua frame yang berbeda dan parameter klasifikasi yang digunakan adalah full body, upper body dan face.

Pengujian sistem dilakukan meggunakan beberapa video sampel yang diambil dengan jarak dan ketinggian kamera terhadap objek berbeda-beda. Hasil yang didapatkan dari pegujian menggunakan video sampel menunjukan tingkat akurasi $95.23 \%$.
\end{abstract}

Kata Kunci: Deteksi Gerak, ADI, Haar Casscade, Motion Detection, Accumulative differences image, Human Detection, Open $C v$

\begin{abstract}
Based on police data quoted from one of the online news portal pages, there are 43,842 thousand criminal acts in the Capital City of Jakarta. Of all these criminal cases burglary empty houses included in the top three acts of crime. Houses that are abandoned by their owners are often targeted by crime operations due to lack of close supervision and security support technology.
\end{abstract}

The purpose of this study is to detect human motion which can later be used to prevent crime in the form of theft. Another purpose of this research is to find out how the method used works in identifying changes in the image of several consecutive frames. This research develops a motion detection system in humans on video using a Closed Circuit Television (CCTV) camera which is simulated using sample video.

The motion detection process uses the Accumulative Differences Image (ADI) method and the human detection process uses the classification of Opencv, the Haar Casscade Classification. Which with this method compares more than two different frames and the classification parameters used are full body, upper body and face.

System testing is done using several video samples taken with the distance and height of the camera against different objects. The results obtained from testing using video samples show an accuracy rate of 95.23\%.

Keywords: Motion Detection, ADI, Haar Cascade, Motion Detection, Accumulative difference image, Human Detection, Open $C$.

\section{Pendahuluan}

$\mathrm{S}$ erdasarkan data kepolisian yang dikutip dari laman salah satu berita online tingkat kejahatan di Indonesia masih tinggi. Dari laporan statistik kriminal 2017, pada tahun 2016 DKI Jakarta merupakan daerah dengan tingkat kejahatan tertinggi di
Indonesia yaitu 43.842 kasus yang artinya rata-rata setiap 11 menit 59 detik terjadi satu kasus kejahatan. [1] Dari semua kasus kejahatan tersebut, pembobolan rumah kosong termasuk dalam kelompok tiga besar dari 22 kategori kriminalitas. Di daerah Ibu Kota Jakarta saja 
kasus pembobolan rumah kosong terjadi merata dihampir seluruh wilayah Ibu Kota tercatat pernah terjadi di 229 kelurahan dari 267 kelurahan yang ada di Jakarta.

Rumah yang ditinggal pemiliknya seringkali dijadikan target sasaran untuk aksi pencurian, sistem keamanan yang kurang ketat membuat para pelaku leluasa untuk melakukan aksi mereka. Kebanyakan aksi pencurian terjadi pada saat rumah kosong dan malam hari ketika pemilik rumah sedang tertidur sehingga aksi lebih leluasa.

Aksi pencurian tersebut dapat dicegah dengan membentuk kelompok ronda atau menggunakan jasa satpam yang sudah terlatih sebelumnya akan tetapi menambah pengeluaran dalam segi materi.

Dukungan teknologi saat ini yang terus berkembang pesat setiap harinya memudahkan untuk melakukan pengawasan dilingkungan sekitar. CCTV (Closed Circuit Television) adalah salah satu perangkat keras yang sering dipasang disudut-sudut rumah dan pertokoan, harga yang bervariasi dan terjangkau membuat banyak masyarakat menggunakan alat ini untuk memantau setiap aktifitas yang ada dilingkungan rumah dan pertokoan.

Pengawasan menggunakan CCTV banyak membantu dalam mengungkap aksi pencurian dan banyak dari kasus yang kerap terjadi para pelaku berakhir dijeruji besi. Tapi masalahnya adalah CCTV hanya merekam aksi kejahatan tanpa adanya sebuah pemberitahuan akan adanya kejahatan yang sedang terjadi secara langsung. Rekaman CCTV digunakan untuk mengidentifikasi pelaku setelah melakukan aksi kejahatan yang artinya pelaku kemungkinan besar berhasil dalam melakukan aksinya.

Melihat hal ini perlu adanya dukungan dari perangkat lunak yang mampu mengidentifikasi setiap pergerakan manusia yang terekam pada CCTV secara langsung.

Aksi dari pencurian dapat diidentifikasi dengan menganalisa perubahan citra antara citra awal dengan citra setelah adanya pergerakan. Pembangunan sistem deteksi gerak pada penelitian ini menggunakan bantuan CCTV dan menggunakan metode Accumulative Differences Images (ADI).

Proses deteksi gerak dilakukan dengan metode Accumulative Differences Images (ADI) dimana dilakukan pada area spasial yaitu membandingkan perbedaan citra pada beberapa frame yang berurutan dari video. Jika dibandingkan dengan metode yang hanya membandingkan perbedaan antara dua frame pada setiap prosesnya, metode ADI dinilai dapat mengurangi error karena diambil dari hasil nilai akumulasi pergerakan dari beberapa frame.[2]

Proses deteksi manusia menggunakan pengklasifikasi terlatih yang terdapat pada library OpenCV. Pada tugas akhir ini, deteksi manusia yang digunakan adalah suatu fungsi yang terdapat di library OpenCV yakni cv2.CasscadeClassifier. Fungsi tersebut membutuhkan file pengklasifikasi yang sudah dilatih untuk mendeteksi objek tertentu. OpenCV menyediakan file tersebut dengan format XML (extensible markup languange) yang terdapat pada folder OpenCV. Pengklasifikasi yang digunakan untuk deteksi manusia adalah kepala dan bahu. Pengklasifikasi ini dipilih karena melalui sudut pandang kamera, bagian kepala dan bahu akan lebih mudah dilihat dibanding bagian lain, seperti wajah, keseluruhan badan, badan bagian atas, atau badan bagian bawah.[3]

\section{STUDI PUSTAKA}

\section{A. Pengolahan Citra Digital}

Citra merupakan gambar yang ada pada bidang dwimatra atau dapat juga dikatakan sebagai gambar dua dimensi. Citra merupakan salah satu komponen multimedia yang memegang peranan penting sebagai informasi visual, serta memiliki karakteristik yang tidak dimiliki oleh data teks. Keluaran citra yang berupa gambar atau foto disebut juga sebagai citra diam. Citra diam adalah citra tunggal yang tidak bergerak, selain itu juga terdapat istilah citra bergerak (moving images) yang artinya ialah rangkaian citra diam yang ditampilkan secara beruntun (sekuensial) sehingga memberi kesan pada mata kita sebagai gambar bergerak. Setiap citra di dalam rangkaian itu disebut frame.[4]

Image processing memiliki masukan dan keluarannya berupa citra, analisa citra (image analysis) memiliki masukan berupa citra dengan keluaran bukan citra akan tetapi berupa hasil pengukuran terhadap citra tersebut, image understanding memiliki masukan berupa citra dengan keluarannya adalah deskripsi tingkat tinggi dari citra tersebut (keluarannya bukan berupa citra), komputer vision bertujuan untuk mengkomputerisasi penglihatan manusia atau dengan kata lain membuat citra digital dari citra sebenarnya (sesuai dengan penglihatan manusia).[5]

Pengolahan Citra Digital (Digital Image Processing) adalah sebuah disiplin ilmu yang mempelajari tentang teknik-teknik mengolah citra. Citra yang dimaksud disini adalah gambar diam (foto) maupun gambar bergerak (yang berasal dari webcam). Sedangkan digital disini mempunyai maksud bahwa pengolahan citra/gambar dilakukan secara digital menggunakan komputer. [6]

\section{B. Citra Grayscale}

Citra grayscale adalah citra digital yang hanya memiliki satu nilai kanal pada setiap pikselnya, dengan kata lain nilai bagian red $=$ green $=$ blue. Citra grayscale memiliki kedalaman warna 8 bit (256 kombinasi warna keabuan). Setiap piksel dari citra warna (8 bit) dengan jumlah warna maksimum yang dapat digunakan adalah 
256 warna. Setiap titik (piksel) pada citra warna mewakili warna yang merupakan kombinasi dari tiga warna dasar yaitu merah, hijau, dan biru yang biasa disebut citra RGB (Red, Green, Blue). Ada dua jenis citra warna 8 bit. Pertama, citra warna 8 bit dengan menggunakan palet warna 256 dengan setiap paletnya memiliki pemetaan nilai (colormap) RGB tertentu. Model ini lebih sering digunakan. Kedua, setiap piksel memilki format 8 bit.[7].

\section{Thresholding}

Thresholding Salah satu metode yang sering digunakan dalam pengolahan citra digital atau image processing adalah thresholding citra. Thresholding citra adalah suatu metode yang digunakan untuk memisahkan antara obyek dan backgroundnya. Thresholding merupakan teknik yang sederhana dan efektif untuk segmentasi citra. Proses thresholding sering disebut dengan proses binerisasi. Pada beberapa aplikasi pengolahan citra, terlebih dahulu dilakukan threshold terhadap citra gray level untuk dapat menjadi citra biner (citra yang memiliki nilai level 0 dan 1). Sebuah citra hasil proses thresholding dapat disajikan dalam histogram citra untuk mengetahui penyebaran nilai-nilai intensitas piksel pada suatu citra/bagian tertentu dalam citra. Histogram dapat dibagi dengan baik (segmentasi objek dengan background) dan dapat ditentukan nilai threshold-nya. Threshold digunakan untuk mengatur jumlah derajat keabuan yang ada pada citra.[8].

\section{Binnary}

Dalam pengolahan citra digital, proses binerisasi adalah mengubah citra grayscale menjadi citra biner, artinya mengubah warna tiap-tiap piksel pada citra bernilai 0 dan 255 ke dalam piksel bernilai 0 dan 1 . Sehingga citra hanya berwarna hitam dan putih. Pada proses binerisasi, menggunakan nilai ambang untuk menentukan nilai grayscale tertentu yang diubah menjadi piksel bernilai 0 atau 1. [9]

\section{E. Otsu}

Metode Otsu merupakan salah satu metode untuk segmentasi citra digital dengan menggunakan nilai ambang secara otomatis, yakni mengubah citra digital warna abu-abu menjadi hitam putih berdasarkan perbandingan nilai ambang dengan nilai warna piksel citra digital. Metode Otsu thresholding diperkenalkan pertama kali oleh Nobuyuki Otsu, dalam jurnal ilmiahnya yang berjudul "A Threshold Selection Method from Grayscale Histogram" pada tahun 1979. Untuk mendapatkan nilai threshold ada perhitungan yang harus dilakukan. Langkah awal yang harus dilakukan adalah membuat histogram. Dari histogram dapat diketahui jumlah piksel untuk setiap tingkat keabuan.[9]

\section{F. OpenCV}

OpenCV (Open Source Computer Vision) adalah library dari fungsi pemrograman untuk realtime visi komputer. OpenCV menggunakan lisensi BSD dan bersifat gratis baik untuk penggunaan akademis maupun komersial. OpenCV dapat digunakan dalam bahasa pemrograman $\mathrm{C}, \mathrm{C}++$, Python, Java, dan sebagainya. OpenCV dapat digunakan pada sistem operasi Windows, Linux, Android, iOS dan Mac OS. OpenCV memiliki lebih dari 2500 algoritma yang telah dioptimalkan. Dalam penelitian ini, penulis menggunakan OpenCV 4.0.0. [10]

OpenCV merupakan library untuk pengolahan citra. Metode-metode penting dalam pengolahan citra kebanyakan sudah ada pada OpenCV. OpenCV juga mudah untuk digunakan dan selain itu OpenCV 2.4 ke atas sudah mengimplementasikan beberapa metodenya pada GPU. OpenCV menggunakan NVidia CUDA dalam implementasi metode-metodenya pada GPU. Metode yang membutuhkan komputasi yang berat menjadi optimal pada GPU dan didapatkan peningkatan kecepatan beberapa kali dibanding dengan CPU tergantung dari kompleksitas metodenya.[11]

\section{METODE PENELITIAN}

Berikut adalah rancangan flowchart dari sistem pendeteksi gerak menggunakan kamera pengawas dengan metode Accumulative Differences Image:

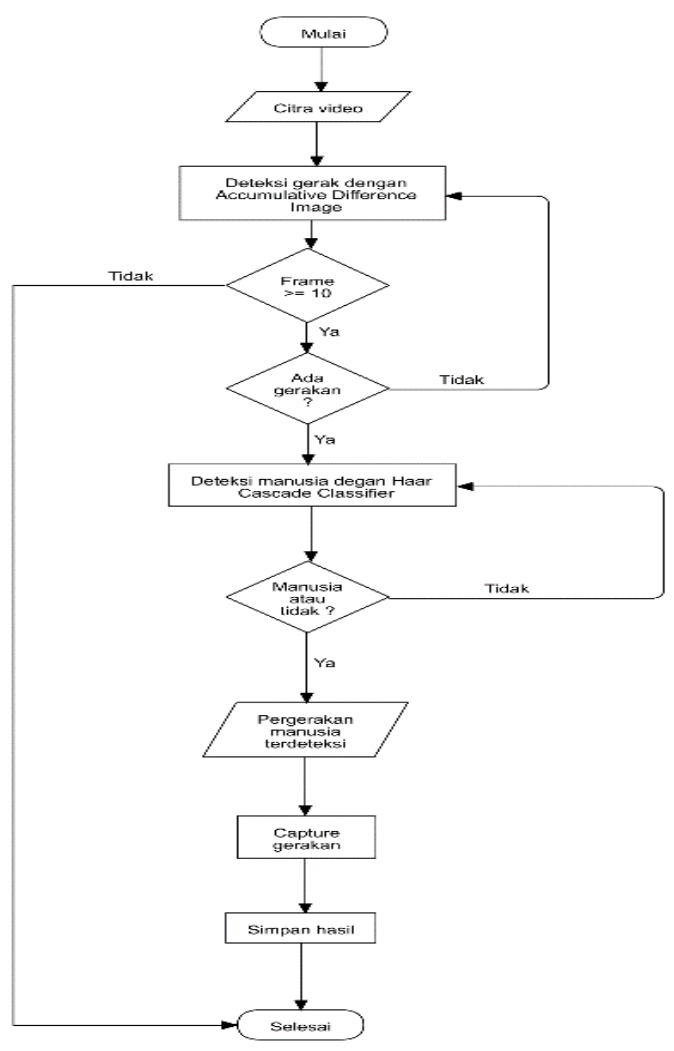

Gambar 1 Perancangan Sistem 
Pada gambar 1 proses dimulai dari pengambilan citra video, lalu pendeteksi gerak menggunakan ADI yang dimana ketika frame mencapai lebih besar atau sama dengan 10 frame maka akan mengecek apakah ada gerakan atau tidak. Jika tidak maka akan kembali mengecek 10 frame berikutnya dari citra video tersebut. Dan jika ada gerakan maka pengecekan selanjutnya dilakukan oleh Haar Casscade Classifier tersebut. Jika tidak terdapat gerakan manusia maka akan kembali mengecek frame selanjutnya. Dan jika terdapat gerakan manusia maka akan menyimpan frame yang terdapat gerakan manusia dalam bentuk citra biner sebanyak 10 frame yang bertumpuk menjadi satu dengan ekstensi .jpg ke dalam hardisk internal dan selesai.

Video simulasi diambil dari berbagai tempat yang berbeda dengan jarak objek dan tinggi kamera yang berbeda-beda disetiap video.

\section{A. Preprocessing Citra}

Tahap preprocessing sendiri terdiri atas beberapa proses yang akan dibahasa satu per satu secara mendetail. Proses tersebut antara lain adalah akusisi citra, konversi citra berwarna kecitra keabuan, konversi citra keabuan menjadi citra biner.

\section{1) Akuisisi Citra}

Pada tahap ini merupakan proses pengambilan citra yang menggunakan smartphone dengan jarak atau tinggi kamera yang berbeda-beda terhadap objek yang bergerak. Yang nantinya akan dijadikan bahan untuk uji coba sistem pendeteksian gerakan manusia. Dengan resolusi citra 1920 X 1080 piksel.

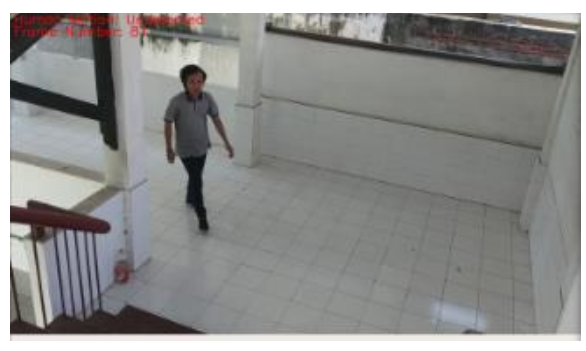

Gambar 1 Akuisisi Citra

Gambar 2 adalah salah satu frame yang diambil dari akuisisi citra yang akan digunakan untuk uji coba. Dengan ukuran piksel 1920 X 1080 pengambilan citra tersebut menggunakan perangkat smartphone.

\section{2) Grayscale}

Proses ini merubah citra berwarna atau citra RGB menjadi citra keabu-abuan atau yang sering disebut dengan Grayscale. Contoh dari konversi citra RGB menjadi keabu-abuan adalah sebagai berikut :

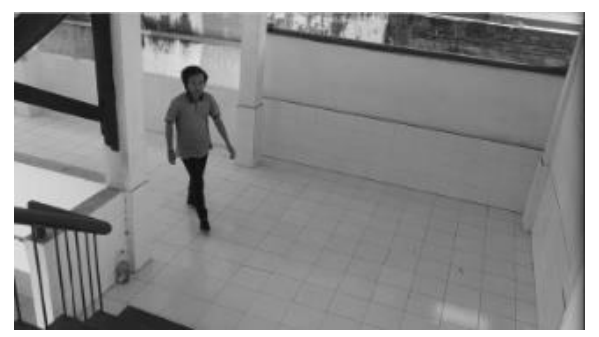

Gambar 2 Grayscale

Pada gambar 3 adalah citra dengan warna keabuan atau Grayscale yang dimana semula gambar berwarna atau RGB dikonversi dengan rumus berikut.

$$
\text { Gray }[0,0]=\frac{R+G+B}{3}
$$

Penjelasan:

$\mathrm{R}=$ Nilai dari $\operatorname{Red}$

$\mathrm{G}=$ Nilai dari Green

$\mathrm{B}=$ Nilai dari Blue

\section{Contoh perhitungan piksel RGB ke Grayscale Tabel 1 Contoh Tabel Piksel RGB}

\begin{tabular}{|c|c|c|c|}
\hline $\mathrm{R}$ & 50 & 200 & 150 \\
$\mathrm{G}$ & 100 & 190 & 75 \\
$\mathrm{~B}$ & 150 & 180 & 50 \\
\hline $\mathrm{R}$ & 60 & 180 & 100 \\
$\mathrm{G}$ & 90 & 190 & 90 \\
$\mathrm{~B}$ & 100 & 200 & 140 \\
\hline $\mathrm{R}$ & 60 & 80 & 100 \\
$\mathrm{G}$ & 50 & 90 & 200 \\
$\mathrm{~B}$ & 70 & 100 & 90 \\
\hline
\end{tabular}

\section{Perhitungan:}

Untuk merubah RGB tersebut kedalam bentuk Grayscale maka perhitungannya seperti dibawah ini.

$$
\begin{aligned}
& G=\frac{50+100+150}{3}=\frac{300}{3}=100 \\
& G=\frac{200+190+180}{3}=\frac{570}{3}=190 \\
& G=\frac{150+75+50}{3}=\frac{275}{3}=91 \\
& G=\frac{60+90+100}{3}=\frac{250}{3}=83 \\
& G=\frac{180+190+200}{3}=\frac{570}{3}=190 \\
& G=\frac{100+90+140}{3}=\frac{330}{3}=110 \\
& G=\frac{60+50+70}{3}=\frac{180}{3}=60
\end{aligned}
$$




$$
\begin{aligned}
& G=\frac{80+90+100}{3}=\frac{270}{3}=90 \\
& G=\frac{100+200+90}{3}=\frac{390}{3}=130
\end{aligned}
$$

Setelah hasil perhitungan setiap piksel didapatkan hasilnya maka pikselnya akan berubah seperti ini.

Tabel 2 Hasil Piksel Grayscale

\begin{tabular}{|c|c|c|}
\hline 100 & 190 & 91 \\
\hline 83 & 190 & 110 \\
\hline 60 & 90 & 130 \\
\hline
\end{tabular}

\section{3) Biner}

Pada tahap ini citra akan diproses menjadi citra yang hanya memiliki nilai 1 dan 0 atau biner. Proses ini melibatkan citra keabu-abuan atau citra Grayscale baru cira tersebut di konversi ke dalam bentuk biner. Contoh citra keabu-abuan dikonversi menjadi citra biner adalah sebagai berikut :

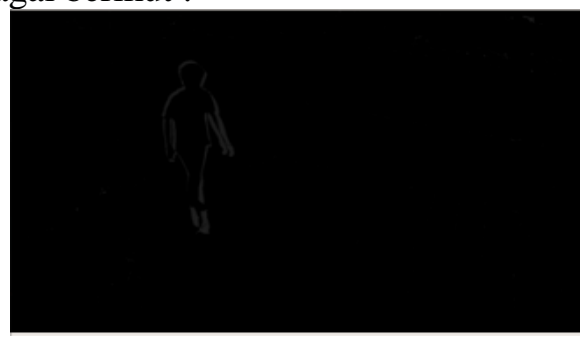

Gambar 3 Citra Binner

Pada gambar 4 terlihat citra dengan warna hitam dan putih yang sebelumnya citra keabuan atau Graysclae. Berikut adalah rumus untuk mengkonversi citra keabuan ke citra biner.

$$
G(x, y)=\left\{\begin{array}{l}
1 f(x, y)>T \\
0 f(x, y)<T
\end{array}\right.
$$

Penjelasan:

$\mathrm{G}(\mathrm{x}, \mathrm{y})=$ Citra Biner

$\mathrm{F}(\mathrm{x}, \mathrm{y})=$ Citra Grayscale

$\mathrm{T}=$ Nilai Thresholding

\section{Merubah Grayscale menjadi Binner}

Dari contoh gambar atau piksel yang sama peroses selanjutnya merubah kedalam bentuk binner dengan ambang batas piksel ditentukan terlebih dahulu atau yang sering disebut dengan Thresholding. Sebagai contoh penulis menggunakan ambang batas yaitu :

$\mathrm{T}=127$

Tabel 3 Tabel Piksel Grayscale

\begin{tabular}{|l|l|l|}
\hline 100 & 190 & 91 \\
\hline
\end{tabular}

\begin{tabular}{|l|l|l|}
\hline 83 & 190 & 110 \\
\hline 60 & 90 & 130 \\
\hline
\end{tabular}

Maka hasil dari table citra grayscale di atas menjadi binner adalah sebagai berikut :

Tabel 2 Tabel Piksel Biner

\begin{tabular}{|c|c|c|}
\hline 0 & 1 & 0 \\
\hline 0 & 1 & 0 \\
\hline 0 & 0 & 1 \\
\hline
\end{tabular}

Keterangan :

$\mathrm{T}=$ Ambang batas (Thresholding)

4) Deteksi Gerak dengan ADI

Setelah citra video melalui bebrapa tahapan atau yang dikenal dengan segmentasi dengan merubah citra berwarna ke dalam citra keabu-abuan dan dilanjutkan dengan mengkonversi citra keabu-abuan menjadi citra biner tahap selajutnya adalah menganalisa setiap frame dari citra video menggunakan metode Accumulative Difference Image (ADI) dengan mengumpulkan beberapa frame dan membandingkannya dengan frame sebelumnya lalu apakah di setiap frame tersebut terdapat perbedaan atau tidak. ADI dapat didefinisikan dalam persamaan berikut.

$$
A k(x, y)=\left\{\begin{array}{cc}
A k-1(x, y)+1 & \text { if }|R(x, y)-f(x, y, k)|>T \\
A k-1(x, y) & \text { otherwise }
\end{array}\right.
$$

\section{HASIL DAN PEMBAHASAN}

Hasil yang didapat dari pengujian sistem yang dilakukan dengan video sampel sebelumnya berupa citra biner, berdasarkan metode yang dipakai untuk mendeteksi gerak yaitu Accumulative Differences Image ini mendeteksi lebih dari dua frame yang berbeda, dipenelitian kali ini digunakan 10 frame dengan ukuran piksel dari setiap frame adalah 1920 X 1080 dan ketika lebih dari sama dengan 10 frame dan itu dinyatakan gerak manusia oleh sistem dengan menggunakan klasifikasi Haar Casscade maka akan di capture dan disimpan kedalam local disk dalam bentuk gambar yang bertumpuk menjadi satu. Berikut adalah hasil deteksi pada salah satu video sampel.

\section{A. Hasil Deteksi Pada Video}

Gambar dibawah ini adalah gambar hasil deteksi pada video sampel yang berisikan enam orang. Berikut adalah hasil deteksi pada video sampel, pada pengujian dengan video sampel ini jarak antara kamera terhadap objek yang bergerak yaitu 2 meter dengan tinggi kamera 1.5 meter. 


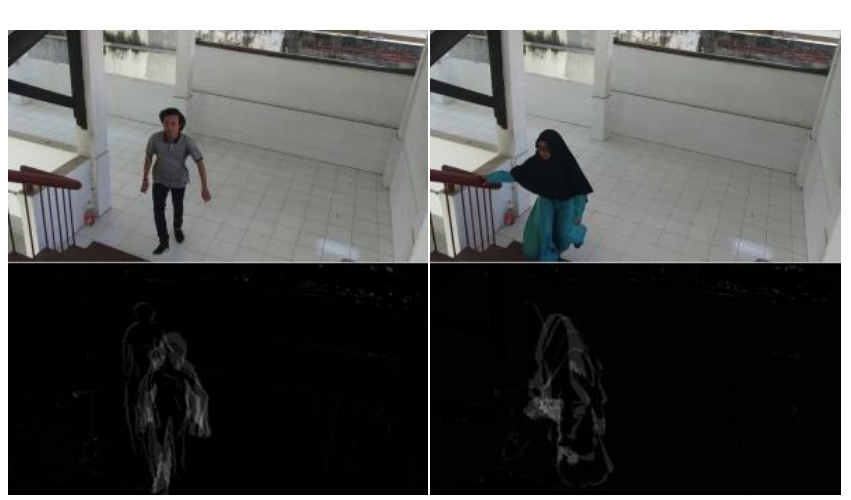

Gambar 5 Hasil Deteksi Video Sampel

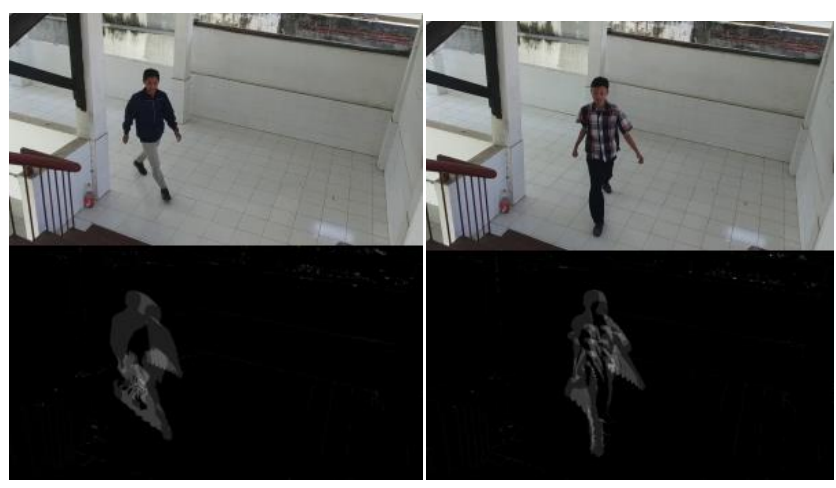

Gambar 6 Hasil Deteksi Video Sampel

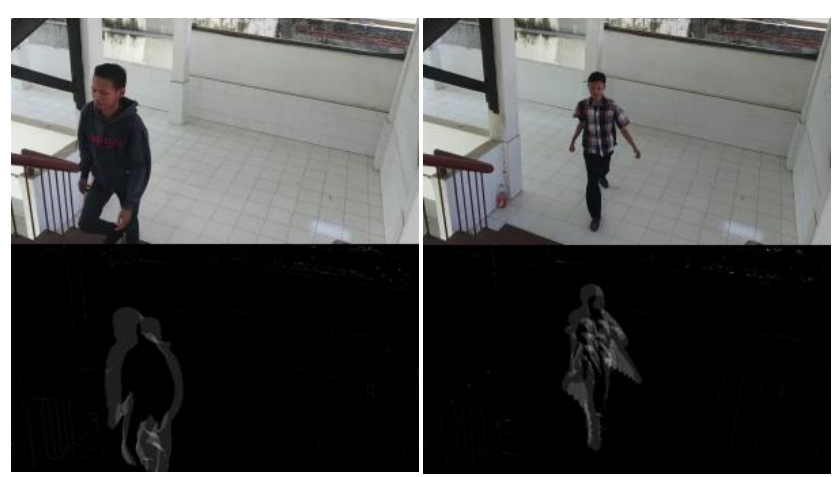

\section{Penjelasan Hasil :}

Gambar 7 Hasil Deteksi Video Sampel

Berdasarkan hasil dari pengujian menggunakan video sampel yang berisi beberapa orang berjalan dan hasil deteksi menujukan setiap gerakan manusia berhasil terdeteksi dengan menggunakan klasifikasi dari Opencv yaitu haar casscade. Teknik pendeteksian dengan mengambil parameter upper body, person atau tubuh keseluruhan dan face atau muka yang dimana nantinya jika didalam video sampel tersebut terdapat muka, bahu atau kepala maka yang akan berperan disitu adalah upper body dan face dari haar casscade. Setelah itu jika berhasil diidentifikasi sebagai gerakan manusia dengan panjang frame lebih dari atau sama dengan 10 maka akan di capture dan disimpan sebagai satu foto yang bertumpuk yang ekstensinya .jpg dan gambar tersebut dalam bentuk citra biner hasilnya bisa dilihat pada gambargambar diatas. Penggunaan metode pendeteksian gerak yang disebut ADI tersebut berhasil diterapkan kedalam sistem dengan mengambil 10 frame jika gerakan lebih dari atau sama dengan batas frame yang sudah ditentukan atau dalam kasus ini pengujian diambil sebanyak 10 frame.

\section{B. Pengujian Sistem}

Dalam pengujian kali ini akan dilakukan dengan lima buah video yang meiliki ukuran piksel setiap frame adalah 1920 X 1080 piksel yang masing-masing video diambil ditempat yang berbeda dengan jarak dan tingi kamera yang berbeda terhadap objek atau manusia. Penggunaan ambang batas atau Thresholding yang sudah ditentukan yang dimana artinya ketika piksel berubah kurang dari ambang batas maka dinyatakan tidak ada gerakan namun ketika piksel berubah diatas atau lebih besar dari ambang batas maka dinyatakan ada pergerakan.

Hasil percobaan yang dilakukan pada 5 data video simulasi yang masing-masing video memiliki jumlah objek/manusia yang berbeda dengan durasi yang berbeda pula yang akan dijadikan dasar untuk perhitungan precission, recall, dan akurasi dari deteksi gerak dengan nilai ambang yang sudah ditentukan sebelumnya. Deteksi akan dihitung satu jika gerakan sudah tidak ada lagi.

Berikut adalah table hasil pengujian sistem menggunakan video sampel sebanyak 5 buah video dengan jumlah objek/manusia yang berbeda-beda.

Tabel 5 Akurasi Hasil Percobaan

\begin{tabular}{|c|c|c|c|c|c|c|}
\hline File Video & Durasi & A & B & C & D & E \\
\hline Person 1.mp4 & $00: 28$ & 3 & 3 & 0 & 0 & 0 \\
\hline Person 2.mp4 & $00: 44$ & 6 & 6 & 0 & 0 & 0 \\
\hline Person 3.mp4 & $00: 49$ & 5 & 5 & 0 & 0 & 0 \\
\hline Person 4.mp4 & $00: 29$ & 5 & 5 & 0 & 0 & 1 \\
\hline Person 5.mp4 & $00: 11$ & 1 & 1 & 0 & 0 & 0 \\
\hline
\end{tabular}

\section{Keterangan :}

$\mathrm{A}=$ Gerak seharusnya

$\mathrm{B}=$ Gerakan manusia terdeteksi oleh sistem (TP)

$\mathrm{C}=$ Ada gerakan manusia tapi tidak terdeteksi (TN)

$\mathrm{D}=$ Tidak terdeteksi pergerakan manusia tapi ada pergerakan manusia (FN)

$\mathrm{E}=$ Tidak ada gerakan manusia tapi terdeteksi (FP)

Menurut hasil gerakan yang dideteksi oleh sistem yang menggunakan metode ADI, dapat dilakukan evaluasi pengujian dengan menggunakan perhitungan Precission, recall, accurate maka didapat hasil sebagai berikut :

$$
\begin{aligned}
& \text { Presicion }=\frac{\mathrm{TP}}{\mathrm{TP}+\mathrm{FP}}=\frac{20}{20+1}=0.95 \times 100=95.23 \\
& \text { Recall }=\frac{\mathrm{TP}}{\mathrm{TP}+\mathrm{FN}}=\frac{20}{20+0}=1 \times 100=100 \%
\end{aligned}
$$




$$
\begin{aligned}
\text { Akurasi } & =\frac{\mathrm{TP}+\mathrm{TN}}{\mathrm{TP}+\mathrm{TN}+\mathrm{FP}+\mathrm{FN}} \\
& =\frac{20+0}{20+0+1+0} \\
& =0.95 \times 100=95.23 \%
\end{aligned}
$$

Berdasarkan hasil dari tabel diatas kinerja deteksi manusia cukup baik dengan nilai True Positive hampir mendominasi semua percobaan. Ini artinya sistem mampu mendeteksi manusia pada saat manusia tersebut ada.

\section{KESIMPULAN}

Berdasarkan uraian hasil dan pembahasan pada bab sebelumnya, maka dapat diambil kesimpulan sebagai berikut:

1. Evaluasi hasil penelitian yang dilakukan terhadap sistem deteksi gerak pada manusia dengan metode Accumulative Differences Image (ADI). Dengan menggunakan klasifikasi Haar Casscade yang dilakukan pada data video simulasi didapatkan nilai precission sebesar $95.23 \%$, dan recall sebesar $100 \%$ sedangkan untuk akurasinya didapatkan nilai $95.23 \%$.

2. Deteksi gerak dengan metode ADI tersebut berhasil menganalisa setiap 10 frame dan menangkap hasil dari gerakan objek dan menyimpannya kedalam bentuk file dengan ekstensi jpg.

3. Berdasarkan hasil pengamatan deteksi gerak manusia menggunakan klasifikasi Haar Casscade masih terdapat beberapa kesalahan atau error deteksi.

4. Jarak objek terhadap kamera yang bisa terdeteksi berkisar antara 2.5 meter dengan tinggi kamera berkisar antara 2 meter.

\section{DAFTAR PUSTAKA}

[1] Budiawan Sidik A. (litbang Kompas), "Ada celah rumah dibobol," Kompas, 2018. [Online]. Available: https://www.pressreader.com/indonesia/kompas/20180422/282321090605037.

[2] A. Priadana and A. Harjoko, "Deteksi Perubahan Citra Pada Video Menggunakan Illumination Invariant Change Detection," IJCCS (Indonesian J. Comput. Cybern. Syst., vol. 11, no. 1, p. 89, 2017.

[3] M. Harry, B. Pratama, A. Hidayatno, and A. Zahra, "Menggunakan Metode Background Subtraction Dengan Algoritma Gaussian Mixture Model," Transient, vol. 6, pp. 246-253, 2017.

[4] R. N. Christianto and Y. D. Prabowo, “Aplikasi Perekam Citra Berdasarkan Pergerakan Objek Yang Nampak," vol. 4, 2017.
[5] T. W. A. Putra, K. Adi, and R. R. Isnanto, "Pengenalan Wajah Dengan Matriks Kookurensi Aras Keabuan Dan Jaringan Syaraf Tiruan Probabilistik," J. Sist. Inf. Bisnis, vol. 02, pp. 1-53, 2013.

[6] A. N. T. RD. Kusumanto, "PENGOLAHAN CITRA DIGITAL UNTUK MENDETEKSI OBYEK MENGGUNAKAN PENGOLAHAN WARNA MODEL NORMALISASI RGB," Semin. Nas. Teknol. Inf. Komun. Terap. 2011 (Semantik 2011), pp. 329-332, 2011

[7] U. S. Utara, "BAB 2 LANDASAN TEORI 2.1 Pengolahan Citra Digital Citra digital dapat didefinisikan sebagai fungsi dua variabel,."

[8] M. Rohman, “Analisa Gerakan Manusia Pada Video Digital."

[9] R. T. Wahyuningrum, "SEGMENTASI OBYEK PADA CITRA DIGITAL MENGGUNAKAN," vol. 13 , no. 1 , pp. 1-8, 2015.

[10] A. Lazaro, J. L. Buliali, and B. Amaliah, "Deteksi Jenis Kendaraan di Jalan Menggunakan OpenCV," vol. 6, no. 2, 2017.

[11] A. Prahara, F. Mipa, and U. G. Mada, "Deteksi Kebakaran pada Video Berbasis Pengolahan Citra dengan Dukungan GPU," pp. 6-11, 2015. 